\title{
Evaluation of the Parasitic Load of Gastrointestinal Nematodes in Bovines
}

\author{
Amalia Cabrera Núñez* and Maria Rebeca Rojas Ronquillo \\ Faculty of Biological and Agricultural sciences, Universidad Veracruz, Mexico
}

Submission: February 05, 2019; Published: February 15, 2019

*Corresponding author: Amalia Cabrera Núñez, $\mathrm{PhD}$ in agricultural education and full-time teacher at the Faculty of Biological and Agricultural sciences, Mexico

\section{Abstract}

This evaluation work was based on evaluating the efficacy of Albendazole $10 \% @$ and Ivermectin at 3.5\%@, against the parasitic load of gastrointestinal nematodes. An investigation was designed for which 50 bovines of the Swiss/Zebu cross were used, with different ages, weight and sex and with a considerable level of parasitic infestation.

\section{Nematode Characteristics}

Gastrointestinal nematodes are widely distributed in tropical and subtropical countries, especially in those regions where pastures are the food base of ruminants, and climatic conditions, mainly Temperature and humidity, encourage hatching and development of eggs to infesting larvae throughout the year [1]. It is important to emphasize that the gastrointestinal parasitic diseases of the ruminants are conditions caused by the presence of helminths, mainly nematodes and baskets and by protozoa of the genus Eimeria [2,3] make known that among the environmental factors the most important are temperature, humidity, rain, sunlight, as well as the action of insects, birds, fungi and the trampling of the animals themselves. The transformation of egg to larva 3 infecting (L3) depends mainly on temperature and humidity. The ideal microenvironment for larvae to develop can only be found within the fecal deposition. These conditions can be altered when the fecal deposition is disaggregated, exposing the larvae to the action of the sun and desiccation, causing a high mortality. The main symptoms of Ostertagia spp infections. They are mucous or aqueous diarrhea with putrid odor, dehydration, edema (submandibular "jaw or bottle jaw"; also ascites, i.e. accumulation of fluid in the abdomen), loss of appetite and weight, and progressive, sometimes fatal weakening. The diagnosis is confirmed by the presence of specific eggs in the stool.

This phylum includes a large number of parasites that affect both domestic animals and man. They are characterized by cylindrical body, without segments with intestinal tract and a common cavity, round shape protected with a cuticle that is moderately resistant to the digestion process. Nematodes are worms distributed in a wide variety of means, some are found freely and others need intermediaries as plants and vertebrate animals and invertebrates to survive. Its biological cycle can be direct or indirect and play an important role as zoonoses [4]. This kind of parasites influences the economy of livestock production due to its high frequency and high morbidity causing problems in development, focusing to almost all organs although in most species the digestive tract is where more They are located, being the following [5].

\section{Control Strategies to the Presence of Nematodes}

The efficacy of Albendazole $10 \% \AA$ and Ivermectin at 3.5\% $₫$ was assessed against the parasitic load of gastrointestinal nematodes. An investigation was designed for which 50 bovines of the Swiss/Zebu cross were used, with different ages, weight and sex and with a considerable level of parasitic infestation. Those that were randomly distributed to form two treatments of 25 animals each. The animals were weighed individually and dosed according to the recommended doses for each product. A sampling was performed on the day of treatment to determine the levels of parasitic infestation with the modified McMaster technique and a mixture of feces was performed by each group to determine the genera present through stool cultures. On the tenth day after treatment, a second sampling was performed to evaluate the reduction of fecal egg count (RCFH\%).

It should be noted that the age of the bovines significantly influenced the presence of the parasitic load. Observing that animals older than one year, showed $96.30 \%$ of positive samples and an average of 33 eggs per gram, while animals under one year had $92.59 \%$ positive to nematodes. These results can be due to the existing conditions of management, the lack of encircled pastures 
and the mating at any time of the year, make it not feasible to separate the animals in different age groups, hence the bovines under a year, They acquire high nematode loads at very young age.

Observed more frequently ostertagia with $43.07 \%$ followed by Cooperia $39.23 \%$ and finally Haemonchus contortus $11.53 \%$ and with lower average Moniezia and nematodiuris (0.76\%) respectively. It should be noted the efficacy of anthelmintics used in this work, with ivermectin at $3.5 \%$ which showed greater efficacy $(100 \%)$ against gastrointestinal nematodes, as well as a reduction in the number of eggs and parasitic larva.

\section{References}

1. Houdijk JGM, Athanasiadou S (2003) Direct and indirect effects of host nutrition on ruminant gastrointestinal nematodes. VI International Symposium on the Nutrition of Herbivores. In: Mannetje L, Ramírez-

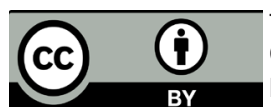

This work is licensed under Creative Commons Attribution 4.0 License

DOI: 10.19080/JDVS.2019.10.555780
Avilés L, Sandoval-Castro CA, Ku-Vera JC (Eds.), Mérida, Yucatán, México pp. 213.

2. Coles GC, Bauer C, Borgsteed FH, Geerts S, Kleit TR, et al. (1992) World Association for the Advancement of Veterinary Parasitology (W.A.A.V.P) methods for the detection of anthelmintic resistance in nematodos of veterinary importance. Veterinary Parasitology 44: 35-44.

3. Steffan PE, Faithful CA (1994) Efectos en producción y control de nematodes gastrointestinales en bovinos [Capítulo 7] Pp.131-153. En: Nari A y Fiel C (Eds.), Enfermedades parasitarias de importancia económica en bovinos. 1ra Edición. Editorial hemisferio sur, Montevideo, Uruguay.

4. Bliss D, Kvasnicka W (1997) The fecal examination: a missing link in food animal practice beef production management. Parasitology, the compendium.

5. Nari A (2003) Resistencia actual a los antiparasitarios. Estado actual con énfasis en América Latina. FAO producción y sanidad animal. Roma, Italy p. 51.

Your next submission with Juniper Publishers
will reach you the below assets
- Quality Editorial service
- Swift Peer Review
- Reprints availability
- E-prints Service
- Manuscript Podcast for convenient understanding
- Global attainment for your research
- Manuscript accessibility in different formats
( Pdf, E-pub, Full Text, Audio)
- Unceasing customer service
Track the below URL for one-step submission
https://juniperpublishers.com/online-submission.php

